\title{
HYALURONIDASE ACTIVITY IN SEMINAL PLASMA AS A METHOD OF ASSESSING BULL SPERM INTEGRITY
}

\author{
J. A. FOULKES AND P. A. WATSON \\ Ministry of Agriculture, Fisheries and Food, \\ Cattle Breeding Centre, Shinfield, Reading RG2 9BZ
}

(Received 4th November 1974)

One of the earliest visual signs of sperm damage is the loss of acrosomal integrity. Consequently, assay of the release into the seminal plasma of hyaluronidase, which is localized in the acrosome (Mancini, Alonsa, Bacquet, Avarez \& Nemirovsky, 1964; Gould \& Bernstein, 1973) should provide an early and sensitive indication of damage sustained by the spermatozoa during processing of semen for artificial insemination (A.I.). Previous biochemical tests of sperm viability have included the assay of phenylalanine $\alpha$-ketoglutarate transaminase released into boar seminal plasma (Gemert, Hendrike \& Van der Horst, 1972). A correlation was found between high enzyme activity in seminal plasma and poor fertility. The release of glutamic oxaloacetic transaminase has been considered an indication of cell damage (Brown, Grabo, Graham \& Pace, 1971) and assay of this non-acrosomal enzyme has been investigated as a measure of sperm damage, although it was not considered that the fertility of a bull could be predicted from such results (Graham \& Pace, 1967; Pace \& Graham, 1970; Breeuwsma, 1972).

The release of hyaluronidase by the spermatozoa is thought to be necessary for penetration of the ovum and has been investigated in studies on capacitation (Austin, 1960; Rogers \& Morton, 1973) and the acrosome reaction (Talbot \& Franklin, 1974). Although the relationship between hyaluronidase activity of spermatozoa in inbred strains of mice and their fertility has been investigated (Erickson \& Krzanowska, 1974), assay of enzyme activity has not been used to monitor sperm integrity or to predict the fertility of semen samples.

Semen was collected from fertile bulls using an artificial vagina and ejaculates from two successive collections were combined. The semen was maintained at $30^{\circ} \mathrm{C}$ in a water-bath, and warmed glassware was used where appropriate. Seminal plasma or diluent was separated from spermatozoa by centrifugation of $1-\mathrm{ml}$ samples over $6 \%(\mathrm{w} / \mathrm{v})$ dextran $-15 \%(\mathrm{w} / \mathrm{v})$ raffinose at $12,000 \mathrm{~g}$ for $10 \mathrm{~min}$ in the MSE 18 swing-out head (Crabo, Bower, Brown, Graham \& Pace, 1971). To avoid dilution of seminal plasma or diluent by dextran-raffinose, only the top $0.5 \mathrm{ml}$ supernatant was removed for assay. Samples of ejaculated or diluted semen $(0.2 \mathrm{ml})$ were also taken and used to provide a measure of the total hyaluronidase content of spermatozoa after freezing and thawing five times.

Hyaluronidase activity was determined after suitable dilution with distilled 
water, using the method of Barrett (1972) with minor modifications. Samples $(0.3 \mathrm{ml})$ were incubated with $0.2 \mathrm{ml}$ hyaluronic acid $(2.5 \mathrm{mg} / \mathrm{ml}$ Grade IIIP from human umbilical cord; Sigma Chemical Co., London) in sodium formate $(0.78 \mathrm{~g} / 100 \mathrm{ml})$ and formic acid buffer ( $\mathrm{pH} 3.8)$ containing $0.375 \mathrm{~m}$-sodium chloride at $37^{\circ} \mathrm{C}$ for $30 \mathrm{~min}$. The reaction was stopped by the addition of $0.1 \mathrm{ml}$ potassium tetraborate buffer $(0.8 \mathrm{M}, \mathrm{pH} 8.9)$ and the samples were placed in a boiling water-bath for $7 \mathrm{~min}$. Enzyme blanks were samples to which the potassium tetraborate was added before incubation. After cooling, $3.0 \mathrm{ml}$ DMAB reagent $(10 \mathrm{~g}$ dimethylaminobenzaldehyde, from Sigma, in $87.5 \mathrm{ml}$ glacial acetic acid and $12.5 \mathrm{ml}$ concentrated $\mathrm{HCl}$ stock solution, diluted ten times in glacial acetic acid) were added and thoroughly mixed. The colour was developed for $7 \mathrm{~min}$ at $37^{\circ} \mathrm{C}$ before the samples were cooled and the optical density at $585 \mathrm{~nm}$ was determined in the Pye Unicam SP 500 spectrophotometer. The $\mathrm{N}$-acetylglucosamine released $/ \mathrm{hr} / \mathrm{ml}$ by the action of hyaluronidase on hyaluronic acid was calculated by reference to a standard curve prepared with $\mathrm{N}$-acetylglucosamine (Sigma). This was found to be linear from 0 to $50 \mu \mathrm{g}$ $\mathrm{N}$-acetylglucosamine/ml. The hyaluronidase activity present in seminal plasma was expressed as a \% of the total hyaluronidase measured in the semen sample frozen and thawed five times to correct for any differences arising from the various proportions of diluent in the samples. Semen was layered over dextranraffinose to allow the use of small samples in the preparation of seminal plasma and to ensure the isolation of any material released by the rupture of spermatozoa on centrifugation.

To investigate the efficacy of this procedure, ejaculated semen from four bulls was divided into two parts, one of which was diluted with 5 vols Diluent A (ultra-heat treated (UHT) skim milk $90 \%$; egg yolk $10 \%$; fructose $1.25 \%$, w/v, plus $500 \mu \mathrm{g}$ streptomycin sulphate $/ \mathrm{ml}$ and 500 i.u. penicillin $/ \mathrm{ml})$. Samples of ejaculated $(1 \mathrm{ml})$ and diluted $(1 \mathrm{ml})$ semen from each bull were layered over $3 \mathrm{ml}$ dextran-raffinose and centrifuged as above. Ejaculated $(3 \mathrm{ml})$ and diluted semen $(3 \mathrm{ml})$ from each bull were similarly centrifuged, without the underlying dense solution. The mean hyaluronidase activity in seminal plasma from four bulls after centrifugation of ejaculated $(7.4 \%)$ or diluted $(5 \cdot 2 \%)$ semen over dextran-raffinose was lower than in seminal plasma from ejaculated $(21.0 \%)$ or diluted $(8.1 \%)$ semen centrifuged alone. This presumably resulted from the better separation of the seminal plasma from the spermatozoa. The results show that semen diluted with Diluent A generally released a lower $\%$ of enzyme activity than ejaculated semen. Either dilution or the presence of diluent reduced the damage occurring to spermatozoa on centrifugation with or without dextran-raffinose.

The release of hyaluronidase by spermatozoa over a period of time was investigated. Ejaculated semen from four bulls was maintained at $30^{\circ} \mathrm{C}$ in a water-bath for $24 \mathrm{hr}$. Hyaluronidase activity released into the seminal plasma was assayed at $10 \mathrm{~min}, 1,2,4,8$ and $24 \mathrm{hr}$ after collection and the total hyaluronidase activity was determined. The initial hyaluronidase activity released into the seminal plasma was about $11 \%$ of the total (Table 1 ). The activity did not increase markedly up to $8 \mathrm{hr}$, but an average of $36.7 \%$ of the total was present in the seminal plasma after $24 \mathrm{hr}$. 
The hyaluronidase activity released by spermatozoa during the routine processing of semen for A.I. was monitored using four collections from each of three bulls. Ejaculated semen was placed at $30^{\circ} \mathrm{C}$ in the water-bath, diluted with Diluent A (above) and cooled to $18^{\circ} \mathrm{C}$. One half of the volume of Diluent B

Table 1. The percentage of total hyaluronidase released into the seminal plasma from ejaculated bull semen maintained at $30^{\circ} \mathrm{G}$ for various times after collections

\begin{tabular}{lrrrrrr}
\hline \multirow{6}{*}{$\begin{array}{c}\text { Bull } \\
\text { No. }\end{array}$} & \multicolumn{6}{c}{ Time after collection } \\
\cline { 2 - 7 } & $10 \mathrm{~min}$ & $1 \mathrm{hr}$ & $2 \mathrm{hr}$ & $4 \mathrm{hr}$ & $\mathbf{8 h r}$ & $24 \mathrm{hr}$ \\
\hline 5 & $10 \cdot 1$ & 12.5 & 14.1 & 14.9 & 15.8 & 22.2 \\
6 & 9.7 & 11.1 & 11.5 & 11.5 & 13.0 & 26.6 \\
7 & 13.6 & & 9.0 & 9.0 & 10.5 & 61.3 \\
& 9.2 & 10.7 & 12.5 & 12.6 & 15.4 & 23.7 \\
& 10.7 & & 20.2 & 22.8 & 27.4 & 54.9 \\
8 & 15.7 & 17.0 & 17.0 & & & 26.4 \\
& 7.6 & & 20.4 & 15.3 & 19.0 & 46.4 \\
& 15.4 & & 13.7 & 14.3 & 13.3 & 32.4 \\
\hline Mean & 11.5 & 12.8 & 14.8 & 14.3 & 16.3 & 36.7 \\
& & & & & & \\
\hline
\end{tabular}

Table 2. The percentage of total semen hyaluronidase activity assayed in seminal plasma during dilution, cooling, freezing and thawing of bovine semen in milkyolk-glycerol diluent

\begin{tabular}{|c|c|c|c|c|c|c|}
\hline $\begin{array}{l}\text { Bull } \\
\text { No. }\end{array}$ & $\begin{array}{l}\text { Ejaculated } \\
\text { semen }\end{array}$ & $\begin{array}{c}\text { Diluted } \\
\text { semen }\left(30^{\circ} \mathrm{C}\right)\end{array}$ & $\begin{array}{c}18^{\circ} \mathrm{C}+ \\
\frac{1}{2} \text { glycerol } \\
\text { fraction* }\end{array}$ & $5^{\circ} \mathrm{C}$ & $\begin{array}{l}5^{\circ} \mathrm{C}+ \\
\text { glycerol } \\
\text { fraction }\end{array}$ & $\begin{array}{c}\text { Frozen } \\
\text { and } \\
\text { thawed }\end{array}$ \\
\hline 9 & $\begin{array}{l}7 \cdot 8 \\
2 \cdot 0 \\
8 \cdot 8 \\
3 \cdot 4\end{array}$ & $\begin{array}{l}3 \cdot 2 \\
4 \cdot 2 \\
4 \cdot 9 \\
4 \cdot 1\end{array}$ & $\begin{array}{l}7 \cdot 5 \\
5.8 \\
5.5 \\
3.5\end{array}$ & $\begin{array}{l}2 \cdot 1 \\
5 \cdot 1 \\
6 \cdot 7 \\
4 \cdot 5\end{array}$ & $\begin{array}{l}8 \cdot 0 \\
8.5 \\
6.2 \\
3.1\end{array}$ & $\begin{array}{r}71.2 \\
25.7 \\
10.0 \\
6.5\end{array}$ \\
\hline 10 & $\begin{array}{r}11.6 \\
7.2 \\
13.9 \\
10.2\end{array}$ & $\begin{array}{l}3 \cdot 2 \\
5 \cdot 1 \\
4 \cdot 2 \\
3 \cdot 8\end{array}$ & $\begin{array}{l}5 \cdot 7 \\
4 \cdot 0 \\
5 \cdot 0 \\
6 \cdot 3\end{array}$ & $\begin{array}{r}5.2 \\
5.6 \\
5.9 \\
15.9\end{array}$ & $\begin{array}{r}3 \cdot 7 \\
10 \cdot 0 \\
4 \cdot 9 \\
3.7\end{array}$ & $\begin{array}{l}11 \cdot 3 \\
14 \cdot 7 \\
21 \cdot 2 \\
14 \cdot 4\end{array}$ \\
\hline 11 & $\begin{array}{l}3 \cdot 1 \\
8 \cdot 4 \\
2 \cdot 6 \\
4 \cdot 9\end{array}$ & $\begin{array}{l}7 \cdot 3 \\
5 \cdot 9 \\
3 \cdot 1 \\
3 \cdot 8\end{array}$ & $\begin{array}{r}16.6 \\
2.9 \\
2.5 \\
2.5\end{array}$ & $\begin{array}{l}6 \cdot 8 \\
4 \cdot 7 \\
4 \cdot 4 \\
3 \cdot 3\end{array}$ & $\begin{array}{l}8 \cdot 8 \\
3 \cdot 1 \\
5 \cdot 8 \\
3 \cdot 9\end{array}$ & $\begin{array}{r}9 \cdot 3 \\
15 \cdot 7 \\
8 \cdot 4 \\
7.9\end{array}$ \\
\hline Mean & $7 \cdot 0$ & 4.4 & $5 \cdot 7$ & 5.9 & $5 \cdot 8$ & $18 \cdot 0$ \\
\hline
\end{tabular}

* For details, see text.

(UHT skim milk $76 \%$; egg yolk $10 \%$; glycerol $14 \%$ and fructose $1.25 \%$ plus $500 \mu \mathrm{g}$ streptomycin sulphate $/ \mathrm{ml}$ and 500 i.u. penicillin $/ \mathrm{ml}$ ) was added and the diluted semen was cooled to $5^{\circ} \mathrm{C}$ before the addition of the remainder 
of Diluent B to provide $120 \times 10^{6}$ spermatozoa $/ \mathrm{ml}$. After equilibration for $3 \mathrm{hr}$, $0.25 \mathrm{ml}$ polyvinyl straws were filled, equilibrated for a' further hour and frozen $4 \mathrm{~cm}$ above the surface of liquid nitrogen. The $\%$ total hyaluronidase activity in the seminal plasma from ejaculated semen, semen obtained after initial dilution, on cooling and dilution at $18^{\circ} \mathrm{C}$, at $5^{\circ} \mathrm{C}$, after equilibration at $5^{\circ} \mathrm{C}$ with the remainder of the glycerol-containing fraction and following thawing of the straws in a water-bath at $30^{\circ} \mathrm{C}$ is shown in Table 2 . The $\%$ activity in seminal plasma was lower after the initial dilution than in ejaculated semen. The sequential cooling procedure and addition of the glycerol-containing fraction of the diluent did not cause a significant rise in hyaluronidase activity assayed in seminal plasma, but after freezing and thawing of straws containing diluted semen a marked rise in seminal plasma hyaluronidase activity was noted.

Since hyaluronidase was not rapidly released from spermatozoa when ejaculated semen was maintained at $30^{\circ} \mathrm{C}$ for a period of $24 \mathrm{hr}$ (Table 1), activity measured in seminal plasma did not result from significant 'background' leakage. Centrifugation of ejaculated or diluted semen over dextran-raffinose to separate seminal plasma limited the release of hyaluronidase activity (see above). No inhibitor of hyaluronidase activity was noted in the seminal plasma. Furthermore, Barrett (1972) reported that the presence of sodium chloride in the incubation medium will prevent inhibition by some contaminants of the substrate preparation, and effectively eliminate the positive interference of $\beta$-glucuronidase or $\beta$-acetylglucosaminidase.

The assay procedure employed was colorimetric and subject to interference from turbidity. This presented some problems during the assay of seminal plasma in diluents containing large quantities of suspended matter, as in milk and egg yolk, and was not overcome by centrifugation. It has been reported that addition of bovine serum albumin (BSA) to the incubation medium will enhance the enzyme activity (Rogers \& Morton, 1973). This would have allowed greater dilution of the seminal plasma before assay and partly have solved the problem, but the inclusion of $10 \mathrm{mg} \mathrm{BSA} / \mathrm{ml}$ led to the formation of a thread-like precipitate as a result of the interaction of the protein and hyaluronic acid. The BSA also contributed to turbidity on the addition of colour reagent in glacial acetic acid. It seems doubtful if the potentiating effect of the BSA would have increased the sensitivity of the assay since a two- to threefold increase in the apparent enzyme activity in the presence of milk and egg yolk-containing diluents was routinely observed.

The increase in hyaluronidase activity in the seminal plasma from the diluted semen in polyvinyl straws after freezing and thawing suggests that acrosomal damage had occurred at this stage and it might be inferred that those samples demonstrating a larger increase in the $\%$ of total hyaluronidase activity would exhibit lower fertility. This proposition is now being tested in a field trial with routine A.I. procedures.

The advice and criticism of Dr E. Linford and the technical assistance of Miss S. Davis are gratefully acknowledged. 


\section{REFERENCES}

Austin, C. R. (1960) Capacitation and the release of hyaluronidase from spermatozoa. F. Reprod. Fert. $1,310-311$.

Barretr, A. J. (1972) Lysosomal enzymes. In Lysosomes. A Laboratory Handbook, pp. 46-135. Ed. J. T. Dingle. North Holland, Amsterdam and London.

Breeuwsma, A. J. (1972) The inter-relationship between seminal glutamic-oxaloacetic transaminase and fertility in bulls. Proc. 7th Int. Congr. Anim. Reprod. $\&$ A. I., Munich, pp. 2129-2132.

Brown, K. I., Grabo, B. G., Graham, E. F. \& Pace, M. M. (1971) Some factors affecting loss of intracellular enzymes from spermatozoa. Cryobiology, 8, 220-224.

Grabo, B. G., Bower, R. E., Brown, K. I., Graham, E. F. \& Pace, M. M. (1971) Extracellular glutamic-oxaloacetic transaminase as a measure of membrane injury in spermatozoa during treat ment. In Current Problems in Fertility, pp. 33-38. Eds. A. Ingelman-Sandberg and N. O. Lunell. Plenum Press, New York and London.

Erickson, R. P. \& Krzanowska, H. (1974) Differences in hyaluronidase activities among inbred strains of mice and their possible significances for variations in fertility. 7 . Reprod. Fert. 39, 101-104.

Gemert, W. V., Hendrike, J. \&. Van der Horst, C. J. G. (1972) The significance of phenylalanine $\alpha$-ketoglutarate transaminase for the qualification of boar semen. Tijdschr. Diergeneesk. 97, 227-234.

Gould, S. F. \& Bernstein, M. H. (1973) Localization of bull sperm hyaluronidase. 7. Cell Biol. 59, 119 a.

Graham, E. F. \& Pace, M. M. (1967) Some biochemical changes in spermatozoa due to freezing. Cryobiology, 4, 75-84.

Mancini, R. E., Alonsa, A., Bacquet, J., Avarez, B. \& Nemirovsky, M. (1964) Histoimmunological localization of hyaluronidase in the bull testis. F. Reprod. Fert. 8, 325-330.

PAce, M. M. \& Graham, E. F. (1970) The release of glutamic oxaloacetic transaminase from bovine spermatozoa as a test method of assessing semen quality and fertility. Biol. Reprod. 3, 140-146.

Rogers, B. J. \& Morton, B. E. (1973) The release of hyaluronidase from capacitating hamster spermatozoa. 7. Reprod. Fert. 35, 477-487.

Talbot, P. \& Franklin, L. E. (1974) The release of hyaluronidase from guinea-pig spermatozoa during the course of the normal acrosome reaction in vitro. 7 . Reprod. Fert. 39, 429-432. 